\title{
The protective action of glycols against freezing damage of mouse and rat embryos
}

\author{
H. Miyamoto and T. Ishibashi \\ Department of Animal Science, College of Agriculture, Kyoto University, Kyoto, Japan
}

\begin{abstract}
Summary. Eight-cell mouse and rat embryos were frozen to $-79^{\circ} \mathrm{C}$ or $-196^{\circ} \mathrm{C}$ in the presence of ethylene, diethylene, triethylene, propylene or polyethylene glycol. Ethylene glycol was the most effective cryoprotectant for mouse and rat embryos and considerable protection against damage during freezing and thawing was also afforded by propylene glycol. The degree of protection given by the other glycols was relatively low. Mouse embryos survived freezing after only $0 \cdot 1 \mathrm{~min}$ exposure to ethylene glycol at $0^{\circ} \mathrm{C}$ but exposure for longer periods was necessary with the other glycols. Mouse embryos that survived freezing and thawing with a glycol as the protective agent were capable of developing to full-term fetuses.
\end{abstract}

\section{Introduction}

The deep freezing of mammalian embryos with glycerol as the cryoprotective agent was first reported for the rabbit but only a few embryos continued to develop in vitro after freezing and thawing (Smith, 1952). Although the freezing of mouse embryos by using polyvinylpyrrolidone (PVP) was reported in 1971 , the embryos did not survive longer than $30 \mathrm{~min}$ at $-79^{\circ} \mathrm{C}$ (Whittingham, 1971a). Whittingham, Leibo \& Mazur (1972) have shown that preservation of mouse embryos by deep freezing can be achieved in the presence of dimethylsulphoxide (DMSO) or glycerol as the cryoprotective agent. The preservation of embryos at very low temperature with DMSO as the cryoprotective agent has been reported for the rat (Whittingham, 1975), rabbit (Bank \& Maurer, 1974; Maurer \& Haseman, 1976), cattle (Wilmut \& Rowson, 1973; Bilton \& Moore, 1977), sheep (Willadsen, Polge, Rowson \& Moor, 1976) and goat (Bilton \& Moore, 1976). No survival was obtained for rabbit embryos frozen in the presence of PVP, glycerol or sodium acetate (Bank \& Maurer, 1974). DMSO has therefore mostly been the cryoprotective agent of choice for freezing embryos. However, ethylene glycol has been shown to protect mouse and rat embryos from freezing damage (Miyamoto \& Ishibashi, 1977) and in the present study we have examined the survival of mouse and rat embryos after freezing and thawing when glycol derivatives are used as the cryoprotective agent.

\section{Materials and Methods}

Female ICR mice, aged 6-15 weeks, were induced to superovulate by intraperitoneal injection of 5 i.u. PMSG followed $48 \mathrm{~h}$ later by 5 i.u. hCG, and were mated. The embryos (8-cell stage) were flushed from the reproductive tracts with a modified Dulbecco's phosphate-buffered salt solution (PBS: Whittingham, 1971a) at 68-70 h after the injection of hCG. Similar 8-cell embryos were obtained, by flushing, from 10-15-week-old Wistar rats on Day 4 of pregnancy (Day 1 is the day on which spermatozoa are found in the vagina) after natural mating.

The embryos were washed in several changes of PBS and 10-22 embryos were transferred to each freezing tube $(10 \times 100 \mathrm{~mm})$ containing $0.1 \mathrm{ml}$ PBS. Except where noted, the tubes were cooled to $0^{\circ} \mathrm{C}$ at $1^{\circ} \mathrm{C} / \mathrm{min}$ in a Dewar flask containing ethanol, and the cryoprotective agent in PBS was added to samples at $0^{\circ} \mathrm{C}$ in three increments of $0.05 \mathrm{ml}$ at $10-\mathrm{min}$ intervals. The cryoprotective agents used were ethylene glycol, diethylene glycol, triethylene glycol, propylene glycol and polyethylene glycol (mol. wt $380-420$ ). The final concentration of glycols was usually $1 \cdot 2 \mathrm{M}$. The samples were equilibrated at 
$0^{\circ} \mathrm{C}$ for 10 min after the addition of glycol, cooled to $-5^{\circ} \mathrm{C}$, and seeded with an ice crystal to induce ice formation. After $5 \mathrm{~min}$ they were cooled to $-79^{\circ} \mathrm{C}$ at approximately $0.5^{\circ} \mathrm{C} / \mathrm{min}$ by adding solid $\mathrm{CO}_{2}$ to ethanol. In some cases the Dewar flasks containing the frozen samples were placed in liquid nitrogen to be cooled from $-79^{\circ} \mathrm{C}$ to $-120^{\circ} \mathrm{C}$ at $1-2^{\circ} \mathrm{C} / \mathrm{min}$, and then samples were transferred directly to liquid nitrogen. After being frozen at $-79^{\circ} \mathrm{C}$ for $0.5-2 \mathrm{~h}$ or at $-196^{\circ} \mathrm{C}$ for $1-24 \mathrm{~h}$, the frozen samples were thawed at approximately $15^{\circ} \mathrm{C} / \mathrm{min}$ in air at room temperature. The rates of cooling and thawing were calculated between $-10^{\circ} \mathrm{C}$ and $-70^{\circ} \mathrm{C}$.

After thawing, the embryos were washed by transfer through three changes of a modified KrebsRinger-bicarbonate medium (Whittingham, 1971b) at room temperature. Mouse embryos were transferred to drops of the modified Krebs-Ringer-bicarbonate medium under paraffin oil, and rat embryos were transferred to drops of the same culture medium containing $10 \%$ fetal calf serum (Whittingham, 1975). All the embryos were then cultured by the microdrop method at $37^{\circ} \mathrm{C}$ for $48 \mathrm{~h}$ in $5 \% \mathrm{CO}_{2}$ in air (Brinster, 1963). Survival of the frozen-thawed embryos was assessed by their ability to develop into expanded blastocysts (mouse) or morulae and blastocysts (rat). Experiments were replicated 4-6 times and data were analysed for statistical significance by $\chi^{2}$ test after confirmation that the results for each treatment were homogeneous.

\section{Results}

In preliminary experiments, mouse embryos were incubated at $0^{\circ} \mathrm{C}$ for $1 \mathrm{~h}$ in the presence of a glycol concentration of $1.2 \mathrm{M}$, except for polyethylene glycol for which the concentration was $0.5 \mathrm{M}$, before being recovered and cultured. There was no significant difference in the development of these embryos to blastocysts $(92-100 \%)$ compared with that $(94-100 \%)$ of control embryos, indicating that exposure to glycols at $0^{\circ} \mathrm{C}$ for $1 \mathrm{~h}$ does not damage the embryos.

Experiment 1. The effect of the number of times glycol was added on the survival of frozen-thawed mouse embryos was examined (Table 1). When $0.15 \mathrm{ml} 2 \mathrm{M}$-ethylene glycol was added directly to embryos suspended in 0.1 ml PBS, the survival was similar to that of embryos to which ethylene glycol had been added in three increments at $10-\mathrm{min}$ intervals. However, direct addition of diethylene, triethylene and polyethylene glycols decreased $(P<0.05)$ the survival of embryos. For the subsequent experiments, therefore, glycols were added to embryos in three increments at 10-min intervals, except as otherwise noted.

Table 1. The effect of the number of times glycol is added on the survival of 8-cell mouse embryos after freezing to $-79^{\circ} \mathrm{C}$

\begin{tabular}{|c|c|c|c|c|}
\hline $\begin{array}{l}\text { Cryoprotective } \\
\text { agent (conc.) }\end{array}$ & $\begin{array}{l}\text { No. of } \\
\text { additions of } \\
\text { glycol }\end{array}$ & $\begin{array}{l}\text { No. of } \\
\text { embryos } \\
\text { frozen }\end{array}$ & $\begin{array}{l}\text { No. of } \\
\text { embryos } \\
\text { recovered }\end{array}$ & $\begin{array}{c}\text { No. of } \\
\text { blastocysts } \\
\text { after culture } \\
(\%)\end{array}$ \\
\hline Ethylene & 1 & 106 & 99 & $85(86)$ \\
\hline glycol $(1 \cdot 2 \mathrm{M})$ & 3 & 63 & 61 & $52(85)$ \\
\hline Diethylene & 1 & 79 & 75 & 32 (43) \\
\hline glycol (1.2 M) & 3 & 73 & 70 & $45(64)$ \\
\hline Triethylene & 1 & 56 & 56 & $31(5.5)$ \\
\hline $\operatorname{glycol}(1 \cdot 2 \mathrm{M})$ & 3 & 59 & 54 & $40(74)$ \\
\hline Propylene & 1 & 61 & 55 & $37(67)$ \\
\hline glycol (1.2 M) & 3 & 53 & 48 & $39(81)$ \\
\hline Polyethylene & 1 & 63 & 60 & $17(28)$ \\
\hline glycol $(0.5 \mathrm{M})$ & 3 & 61 & 61 & $40(66)$ \\
\hline
\end{tabular}

Experiment 2. Glycol concentration was found to be the factor affecting survival of mouse embryos frozen to $-79^{\circ} \mathrm{C}$ and thawed (Table 2). Concentrations of 0.9-1.5 M-ethylene glycol, 0.9-1.8 Mdiethylene glycol, 0.6-1.5 M-triethylene glycol, 1.2-1.8 M-propylene glycol, and 0.5-0.7 M-polyethylene 
glycol appeared to be the most successful $(P<0 \cdot 05)$ under the present experimental conditions, and for subsequent studies the glycol concentration was $1.2 \mathrm{M}$ except for polyethylene glycol for which $0.5 \mathrm{M}$ was used.

Table 2. The effect of concentration of glycol on the percentage development of 8-cell mouse embryos to expanded blastocysts after freezing to $-79^{\circ} \mathrm{C}$, thawing and culture for $48 \mathrm{~h}$

\begin{tabular}{cccccc}
\hline $\begin{array}{c}\text { Glycol } \\
\text { conc. (M) }\end{array}$ & $\begin{array}{c}\text { Ethylene } \\
\text { glycol }\end{array}$ & $\begin{array}{c}\text { Diethylene } \\
\text { glycol }\end{array}$ & $\begin{array}{c}\text { Triethylene } \\
\text { glycol }\end{array}$ & $\begin{array}{c}\text { Propylene } \\
\text { glycol }\end{array}$ & $\begin{array}{c}\text { Polyethylene } \\
\text { glycol }\end{array}$ \\
\hline 0.3 & $0(49)$ & $0(50)$ & $0(43)$ & $0(55)$ & $20(54)$ \\
0.4 & - & - & - & - & $28(61)$ \\
0.5 & - & - & $71(56)$ & $4(69)$ & $55(53)$ \\
0.6 & $9(66)$ & $26(54)$ & - & - & $33(55)$ \\
$0 \cdot 7$ & - & - & $74(68)$ & $68(66)$ & $15(48)$ \\
0.9 & $91(69)$ & $47(60)$ & $77(60)$ & $80(60)$ & - \\
$1 \cdot 2$ & $87(60)$ & $64(55)$ & $62(68)$ & $86(66)$ & - \\
1.5 & $81(57)$ & $41(54)$ & $18(60)$ & $76(63)$ & - \\
1.8 & $71(55)$ & $52(61)$ & $13(61)$ & $61(69)$ & - \\
$2 \cdot 1$ & $59(61)$ & $35(52)$ & & & - \\
\hline
\end{tabular}

Figures in parentheses represent the no. of thawed embryos recovered.

Experiment 3. To determine whether the duration of exposure of mouse embryos to glycols at $0^{\circ} \mathrm{C}$ before freezing had any effect upon survival of frozen-thawed embryos, the embryos were kept in the glycols at $0^{\circ} \mathrm{C}$ for various periods after the direct addition of the PBS containing glycols and frozen to $-79^{\circ} \mathrm{C}$. As shown in Table 3 the time of exposure of mouse embryos to glycols was important. Although a high proportion of the embryos was protected after exposure to ethylene glycol at $0^{\circ} \mathrm{C}$ for only $0.1 \mathrm{~min}$, exposure to the other glycols for 0.1 to $5 \mathrm{~min}$ gave low survival rates compared with those of embryos exposed for longer times (15-60 $\mathrm{min}$ ).

Table 3. The effect of equilibration time to glycol at $0^{\circ} \mathrm{C}$ before freezing on the percentage development to expanded blastocysts of 8 -cell mouse embryos frozen to $-79^{\circ} \mathrm{C}$

\begin{tabular}{cccccr}
\hline $\begin{array}{c}\text { Equilibration } \\
\text { time (min) }\end{array}$ & $\begin{array}{c}\text { Ethylene } \\
\text { glycol }\end{array}$ & $\begin{array}{c}\text { Diethylene } \\
\text { glycol }\end{array}$ & $\begin{array}{c}\text { Triethylene } \\
\text { glycol }\end{array}$ & $\begin{array}{c}\text { Propylene } \\
\text { glycol }\end{array}$ & $\begin{array}{c}\text { Polyethylene } \\
\text { glycol }\end{array}$ \\
\hline $0 \cdot 1$ & $87(54)$ & $10(52)$ & $11(56)$ & $0(57)$ & $0(47)$ \\
5 & $81(42)$ & $16(55)$ & $31(64)$ & $0(59)$ & $6(48)$ \\
15 & $85(48)$ & $44(55)$ & $57(56)$ & $33(63)$ & $11(56)$ \\
30 & $80(45)$ & $60(60)$ & $53(51)$ & $74(54)$ & $27(60)$ \\
60 & $73(40)$ & $59(51)$ & $58(64)$ & $53(57)$ & $36(56)$ \\
\hline
\end{tabular}

Figures in parentheses represent the no. of thawed embryos recovered.

Experiment 4. The survival of 8-cell mouse and rat embryos after freezing and thawing in the presence of glycols is summarized in Table 4. Mouse embryos survived better than rat embryos with all the glycols tested. Ethylene glycol was the most effective protective agent for mouse embryos at -79 and $-196^{\circ} \mathrm{C}(P<0.02)$ but propylene glycol also had considerable effect. These two glycols were the most effective for rat embryos as well.

Experiment 5. The potential for survival of the 8-cell mouse embryos frozen to $-196^{\circ} \mathrm{C}$ was tested by transferring the blastocysts which had expanded after $48 \mathrm{~h}$ in culture to the uterine horns of pseudopregnant females (5-10 blastocysts/horn), mated with vasectomized males. The recipients were killed on the 18th day of pregnancy. As shown in Table 5 thawed mouse embryos protected by glycols were capable of developing to full-term fetuses. 
Table 4. Survival of 8-cell mouse and rat embryos after freezing and thawing in the presence of glycol

\begin{tabular}{|c|c|c|c|c|c|}
\hline $\begin{array}{c}\text { Cryoprotective } \\
\text { agent }\end{array}$ & $\begin{array}{c}\text { Freezing } \\
\text { temp. } \\
\left({ }^{\circ} \mathrm{C}\right)\end{array}$ & $\begin{array}{l}\text { No. of } \\
\text { embryos } \\
\text { frozen }\end{array}$ & $\begin{array}{l}\text { No. of } \\
\text { embryos } \\
\text { recovered }\end{array}$ & $\begin{array}{c}\text { No. of } \\
\text { morulae } \\
\text { after } \\
\text { culture } \\
\%\end{array}$ & $\begin{array}{l}\text { No. of } \\
\text { blastocysts } \\
\text { after } \\
\text { culture } \\
(\%)\end{array}$ \\
\hline \multicolumn{6}{|l|}{ Mouse } \\
\hline \multirow[t]{2}{*}{ Ethylene glycol } & -79 & 131 & 128 & - & $112(88)$ \\
\hline & -196 & 61 & 58 & - & $50(86)$ \\
\hline \multirow[t]{2}{*}{ Diethylene glycol } & -79 & 131 & 126 & - & $80(63)$ \\
\hline & -196 & 64 & 59 & - & $25(42)$ \\
\hline \multirow[t]{2}{*}{ Triethylene glycol } & -79 & 130 & 125 & - & $74(59)$ \\
\hline & -196 & 67 & 66 & - & $30(45)$ \\
\hline \multirow[t]{2}{*}{ Propylene glycol } & -79 & 133 & 124 & - & $94(76)$ \\
\hline & -196 & 68 & 62 & - . & $42(68)$ \\
\hline \multirow[t]{2}{*}{ Polyethylene glycol } & -79 & 114 & 107 & - & $52(49)$ \\
\hline & -196 & 59 & 58 & - & $21(36)$ \\
\hline \multicolumn{6}{|l|}{ Rat } \\
\hline \multirow[t]{2}{*}{ Ethylene glycol } & -79 & 66 & 62 & $4(6)$ & $32(52)$ \\
\hline & -196 & 53 & 51 & $4(8)$ & $20(39)$ \\
\hline \multirow[t]{2}{*}{ Diethylene glycol } & -79 & 68 & 66 & $6(9)$ & $20(30)$ \\
\hline & -196 & 59 & 53 & $3(6)$ & $15(28)$ \\
\hline \multirow{2}{*}{ Triethylene glycol } & -79 & 63 & 58 & $4(7)$ & $19(33)$ \\
\hline & -196 & 61 & 56 & $6(11)$ & $12(21)$ \\
\hline \multirow[t]{2}{*}{ Propylene glycol } & -79 & 66 & 64 & $4(6)$ & $28(44)$ \\
\hline & -196 & 64 & 62 & $3(5)$ & $20(32)$ \\
\hline \multirow[t]{2}{*}{ Polyethylene glycol } & -79 & 55 & 53 & $4(8)$ & $15(28)$ \\
\hline & -196 & 51 & 50 & $3(6)$ & $10(20)$ \\
\hline
\end{tabular}

* The concentration of glycols was $1.2 \mathrm{M}$ except for that of polyethylene glycol which was $0.5 \mathrm{M}$.

Table 5. Development of 8-cell mouse embryos frozen to $-196^{\circ} \mathrm{C}$ in the presence of glycol to full-term fetuses after culturing for $48 \mathrm{~h}$ and transferring to pseudopregnant females

\begin{tabular}{|c|c|c|c|c|c|}
\hline $\begin{array}{c}\text { Cryoprotective } \\
\text { agent }\end{array}$ & $\begin{array}{l}\text { No. of } \\
\text { blastocysts } \\
\text { transferred }\end{array}$ & $\begin{array}{l}\text { No. of } \\
\text { recipients }\end{array}$ & $\begin{array}{c}\text { No. of } \\
\text { pregnant } \\
\text { recipients }\end{array}$ & $\begin{array}{l}\text { No. of } \\
\text { blastocysts } \\
\text { transferred } \\
\text { to recipients }\end{array}$ & $\begin{array}{l}\text { No. of } \\
\text { fetuses }\end{array}$ \\
\hline Ethylene glycol & 45 & 6 & 2 & 18 & 10 \\
\hline Diethylene glycol & 35 & 4 & 1 & 7 & 3 \\
\hline Triethylene glycol & 18 & 3 & 1 & 7 & 4 \\
\hline Propylene glycol & 41 & 5 & 2 & 14 & 8 \\
\hline Polyethylene glycol & 52 & 6 & 1 & 10 & 3 \\
\hline
\end{tabular}

\section{Discussion}

Lovelock (1954) found that none of the neutral solutes was as effective as glycerol for protecting human erythrocytes against freezing injury, that ethylene, diethylene and propylene glycols were effective, and that triethylene glycol gave only a little protection and polyethylene glycol gave none. Ethylene, diethylene and propylene glycols are able to protect aneuploid cells from human kidney against damage during freezing and thawing (Vos \& Kaalen, 1965). Doebbler \& Rinfret (1962) observed correlation between the hydrogen-bonding capacities of cryoprotective agents and their 
protective capacities, suggesting that the ability to bind or to substitute for water might be an important factor. Glycol derivatives have strong hydrogen bonding and numerous hydrogen-bonding sites (Doebbler, 1966).

The results of the present and a previous investigation (Miyamoto \& Ishibashi, 1977) show clearly that a high proportion of 8-cell mouse and rat embryos can survive freezing to $-196^{\circ} \mathrm{C}$ when ethylene glycol is the cryoprotective agent, and ethylene glycol would appear to be the most protective agent of the glycol derivatives tested for freezing mouse and rat embryos under the present conditions of a $1.2 \mathrm{M}$ cryoprotectant concentration, an equilibration temperature of $0^{\circ} \mathrm{C}$, a cooling rate of $0.5^{\circ} \mathrm{C} / \mathrm{min}$ and a thawing rate of $15^{\circ} \mathrm{C} / \mathrm{min}$. Considerable protection against damage during freezing and thawing was also found for propylene glycol but the protection afforded by diethylene, triethylene and polyethylene glycols was less.

The development of rat embryos in these conditions is low compared with that in the mouse (Whittingham, 1975; the present study), presumably because of species differences in the embryo responses to freezing and thawing. It is possible that greater survival of rat embryos could be obtained by changes of the freezing and thawing procedures in the presence of glycols.

Although DMSO in PBS is usually added directly to mouse embryos at $0^{\circ} \mathrm{C}$ (Whittingham et al., 1972; Leibo, Mazur \& Jackowski, 1974), in the present study direct addition of glycols (except ethylene glycol) at $0^{\circ} \mathrm{C}$ damaged the embryos and stepwise additions were necessary.

The equilibration time to glycols other than ethylene glycol was found to be an important factor, and a period of 15-60 min was necessary to give survival rates of about $50 \%$ : ethylene glycol was effective at all times tested, even after exposure for as little as $0.1 \mathrm{~min}$. During the first $10 \mathrm{~min}$ of exposure to ethylene glycol at 0 to $1^{\circ} \mathrm{C}$ mouse embryos shrink and have not fully attained their normal volume even after $60 \mathrm{~min}$ of exposure (Miyamoto \& Ishibashi, 1977). The differences between the cryoprotective characteristics of the various glycols may be due to differences in the ease with which they permeate the embryos and this possibility is being investigated further.

The low pregnancy rate after transfer of mouse embryos frozen-thawed in the presence of glycols (Table 5) may be due to the diversity of techniques used or to the degree of protection afforded by the glycols against freezing damage. The survival of mouse embryos after freezing in the presence of DMSO has been achieved by relatively slow freezing and thawing rates, of the order of $0.2-0.8^{\circ} \mathrm{C} / \mathrm{min}$ and $4-25^{\circ} \mathrm{C} / \mathrm{min}$, respectively (Whittingham et al., 1972; Wilmut, 1972). The optimal cooling and thawing rates change with the concentration of the cryoprotective agent (Wilmut, 1972), and may also differ markedly for different cryoprotective agents. Further experiments are needed to establish whether other conditions of equilibration temperature and freezing and thawing rates for mouse and rat embryos will give better results with glycols as the cryoprotective agent.

\section{References}

Bank, H. \& Maurer, R.R. (1974) Survival of frozen rabbit embryos. Expl Cell Res. 89, 188-196.

Bilton, R.J. \& MOORE, N.W. (1976) In vitro culture, storage and transfer of goat embryos. Aust. J. biol. Sci. 20, 125-129.

Bilton, R.J. \& MoORE, N.W. (1977) Successful transport of frozen cattle embryos from New Zealand to Australia. J. Reprod. Fert. 50, 363-364.

Brinster, R.L. (1963) A method for in vitro cultivation of mouse ova from two-cell to blastocyst. Expl Cell Res. 32, 205-208.

Doebrler, G.F. (1966) Cryoprotective compounds. Review and discussion of structure and function. Cryobiology 3, 2-11.

Doebbler, G.F. \& Rinfrét, A.P. (1962) The influence of protective compounds and cooling and warming conditions on hemolysis of erythrocytes by freezing and thawing. Biochim. biophys. Acta 58, 449-458.
Leibo, S.P., MazuR, P. \& JACKowsKi, S.C. (1974) Factors affecting survival of mouse embryos during freezing and thawing. Expl Cell Res. 89, 79-88.

LOVELOCK, J.E. (1954) The protective action of neutral solutes against haemolysis by freezing and thawing. Biochem. J. 56, 265-270.

Maurer, R.R. \& Haseman, J.K. (1976) Freezing morula stage rabbit embryos. Biol. Reprod. 14, 256-263.

MiYamoto, H. \& Ishibashi, T. (1977) Survival of frozenthawed mouse and rat embryos in the presence of ethylene glycol. J. Reprod. Fert. 50, 373-375.

Smith, A.U. (1952) Behaviour of fertilized rabbit eggs exposed to glycerol and to low temperatures. Nature, Lond. 170, 374-375.

Vos, O. \& KaAleN, M.C.A.C. (1965) Prevention of freezing damage to proliferating cells in tissue culture. A quantitative study of a number of agents. Cryobiology 1, 249-260. Downloaded from Bioscientifica.com at 04/26/2023 10:03:34AM 
WhITTINGHAM, D.G. (1971a) Survival of mouse embryos after freezing and thawing. Nature, Lond. 233, 125126.

WhItTINGHAM, D.G. (1971b) Culture of mouse ova. J. Reprod. Fert., Suppl. 14, 7-21.

WhitTINGHAM, D.G. (1975) Survival of rat embryos after freezing and thawing. J. Reprod. Fert. 43, 575578.

Whittingham, D.G., Leibo, S.P. \& Mazur, P. (1972) Survival of mouse embryos frozen to $-196^{\circ} \mathrm{C}$ and $-269^{\circ} \mathrm{C}$. Science, N.Y. 178, 411-414.
Willadsen, S.M., Polge, C., Rowson, L.E.A. \& Moor, R.M. (1976) Deep freezing of sheep embryos. $J$. Reprod. Fert. 46, 151-154.

WiLMUT, I. (1972) Effect of cooling rate, warming rate, cryoprotective agent and stage of development on survival of mouse embryos during cooling and thawing. Life Sci. 11, 1071-1079.

Wirmut, I. \& Rowson, L.E.A. (1973) Experiments on the low-temperature preservation of cow embryos. Vet. Rec. 92, 686-690.

Received 27 April 1978 